4th International Scientific Conference SEC-IASR 2019,

Galati, Romania, 7th - 8th June, 2019

\title{
Tax Optimization at the Level of Sports Clubs
}

\author{
Florentina MOISESCU \\ https://doi.org/10.18662/lumproc/sec-iasr2019/25
}

How to cite: Moisescu, F. (2020). Tax Optimization at the Level of Sports Clubs. In S. Marin \& P. Moisescu (vol. eds.), Lumen Proceedings: Vol. 12. 4th International Scientific Conference SEC-IASR 2019 (pp. 240-245). Iasi, Romania: LUMEN Publishing House. https://doi.org/10.18662/lumproc/sec$\underline{\text { iasr2019/25 }}$ 


\title{
Tax Optimization at the Level of Sports Clubs
}

\author{
Florentina MOISESCU ${ }^{1}$
}

\begin{abstract}
The paper deals with the way in which sport clubs resort to tax optimization in order to avoid the fulfilment of their obligations towards the general budget, which is established by speculating, for their benefit, the content of the legal rules applicable in the matter, which allow the choice of a particular tax regime, advantageous to them. Tax optimization is an important point in effective asset management strategies. In tax law there is the principle that any company is free to organize its activity in order to optimize their tax and payments and, as a result, most companies try to find legal ways to pay lower taxes. However, it often happens that tax optimization is mistook for tax evasion and moralizing speeches appear in a field considered immoral from the start. However, tax optimization implies law enforcement and includes any immediate measure likely to reduce the tax costs associated with a specific operation/transaction. We can therefore conclude that tax optimization represents a thorough understanding of the business of the sports organization, its mechanisms and limitations, as well as finding those routes offered by both local and international tax laws that lead to the reduction of the amount and the postponement of the tax charge as much as possible, so that the company can reduce or better manage the impact of cash flow.
\end{abstract}

Keywords: tax optimization; sport club; management strategies.

1 "Dunarea de Jos" University of Galati, Romania, florentina.moisescu@ugal.ro 


\section{Introduction}

According to international law and practice no one is obliged to pay more than what is included in the tax legislation. Therefore, it is the taxpayer's right to decide: how he will comply with the tax legislation; where he will accept to work and be taxed; who will become the subject of taxation and the payer of tax liabilities: as a natural or legal person, resident or nonresident, etc.

Fiscal optimisation is defined as the technique by which the taxpayer makes a choice among various solutions offered by the tax legislation in the most favourable sense of their own interests. It is a permissible fact, excluding any criminal offence or contravention. The main taxes and dues of which the entities can choose to optimize the tax vector are the following: income tax on wages and assimilated wages; the income tax of microenterprises; corporation tax; value added tax, a.o. Thus, tax optimisation ensures a competitive advantage before competitors and allows the entity to save its financial resources.

The paper addresses the issue of fiscal optimisation of sports clubs in Romania and the role of their legal structure.

\section{Literature review}

Over the years many authors have approached the problem of tax burdens. Daniel Defoe, in his work The political history of The Devil (1726) noted: "I do not believe there are things safer than death and taxes." Consistently, tax laws provide options for: tax registration, tax regime, accounting regime or declarative regime [1]. But the frequency and forms of use of tax optimisation depend on the degree of mobility of the activity and the capital: internal tax optimization, international tax optimization [2].

\section{Research Questions}

In this paper we will pay particular attention to the type of legal structure of sports clubs and answer the question: to what extent the legal structure of sports clubs in Romania is used as a tax planning tool.

The question also arises: where does tax optimization end and where does tax evasion begin? Tax evasion is a concept on which there are several points of view but, it is generally accepted that it consists in the avoidance of tax or compliance with the obligation to pay taxes or dues established by law. 


\section{Research Methods}

The informational support of the research is the official statistical data taken from the documents of the Ministry of Youth and Sports in Romania, the Romanian Statistical Yearbook, the Strategy for Sports Development in Romania- 2016-2032 and the authors' own analyses. The application was used as a research instrument under Windows, Microsoft Office Professional 2010.

The methodology of the research involved the use of the following methods: analysis and synthesis, observation, reasoning, comparison, classification, grouping and statistical methods that allowed a thorough analysis of the various economic investigated phenomena.

\section{Form of organization - Fiscal planning tool}

The basic instruments of tax planning are [3]: territorial jurisdiction; the type of legal structure of the entity; the board of founders (owners); the formation of social capital; accounting and fiscal policy method; modification of contractual relations; division of legal relations; postponement of the payment period of taxes and dues; reduction of the taxable base; off-shores; delegation of tax obligations to the satellite entity (parallel business); implementation of national tax facilities (regimes); etc.

The choice of its legal structure influences the way the entity is taxed. Thus, joint-stock and limited liability companies pay 16\% corporate tax and the micro-enterprises pay only $3 \%$ income tax. As a limited liability company not liable for value added tax, none of the VAT costs can be inferred, fact which can be translated into a higher corporation/income tax. Nonprofit organizations are exempted from corporation tax and for income from economic activities earned up to the equivalent amount of 15,000 Lei in Euros during a fiscal year, but not more than $10 \%$ of total revenues exempted from corporation tax payment [4].

According to Law no. 69/2000 [5], sports structures are associations of private law, consisting of natural or legal persons, constituted for the purpose of organising and administering a sporting activity and aiming to promote one or more sports disciplines, their practice by their members and participation in sporting activities and competitions. From a legal point of view, sports clubs can be:

a) legal persons of private law, non-profit structures or joint-stock sports companies;

b) legal persons under public law. 
According to the public information available on the MTS (Ministry of Youth and Sports) website [6], Romania operates 77 sports federations, 288 department sports clubs and 123 urban sports clubs spread throughout the country.

Sports clubs under public law are legal persons, established as public institutions subordinated to state administration bodies, and have as their object of activity the performance, selection, preparation and participation in internal and international competitions. They may receive for administration or on loan for use buildings for sporting activity, sports facilities and equipment.

In Romania, over $90 \%$ of the revenues of sports clubs under public law come from the local authorities, and the rest from other sources (ticket sales, sponsors, marketing activities). The funds allocated to sports activities (during 2006-2018) reached around 0.05\% of the G.D.P. [7] and were carried out through the Directorates for Sport and Youth until 2011, when this mechanism ceased to work by no longer being allocated funds (table 1). Local authorities have taken over this financing mechanism and established their own funding regulations and annual budgets, allocated to nongovernmental organizations and implicitly to sports projects on nonrefundable grants. Thus, both county councils and local councils funded sports projects of public interest.

Tabel 1.Situation of the financing of the national sports federations and of the Romanian Olympic and Sporting Committee in the period 1999 - 2016

\begin{tabular}{lrrrr}
\hline Years & \multicolumn{2}{c}{ National Sports Federations } & \multicolumn{2}{c}{ Jlympic and Sports Committee } \\
\hline $1999-2000$ & 29.933 .834 & 8.147 .844 & 11.176 .656 & 0 \\
$2001-2004$ & 118.046 .918 & 10.042 .480 & 54.050 .043 & 14.060 .727 \\
$2005-2008$ & 239.286 .177 & 20.503 .553 & 92.791 .143 & 30.499 .157 \\
$2009-2012$ & 310.333 .818 & 32.484 .174 & 68.662 .280 & 69.308 .331 \\
2013 - 2016 & 297.705 .574 & 103.501 .943 & 75.603 .485 & 103.750 .917 \\
\hline Source: author's processing based on the Sport Development Strategy in Romania in the period 2016 - \\
2032, http://mts.ro/ wp-content/ uploads/2016/06/strategie-sport-pdf
\end{tabular}

Sports clubs organized as commercial sports companies are professional sports clubs. They are subject to participation in professional sports competitions, promoting and developing sporting activities, as well as other activities related to or derived from their social purpose. Professional sports clubs are organized only for one sporting discipline and they have the legal status of commercial companies. In Romania there are 69 sports structures-stock companies and 3843 private sports structures/clubs. In 
general, the clubs - the stock companies operate as "closed companies" , therefore a lot of financial information is not known. The transformation of sports clubs into "open companies" by being listed in the Bucharest Stock Exchange (BVB) would bring a number of financial and non-financial benefits, even if their level of taxation increases, too. As proof, the owners of the great football teams in Europe have chosen to enlist to the stock exchanges in their countries, not necessarily from the need to obtain finance through the issue of shares, but more for the sake of supporters. In some cases, like Chelsea or Manchester United, the stock listing has relieved their takeover by a single big investor.

In the world stock exchanges there are dozens of companies that manage football teams. 23 of them, both big clubs and small clubs, are included in a pan-European soccer stock market index, the STOXX Europe Football Index [8], the evolution of which is presented below.

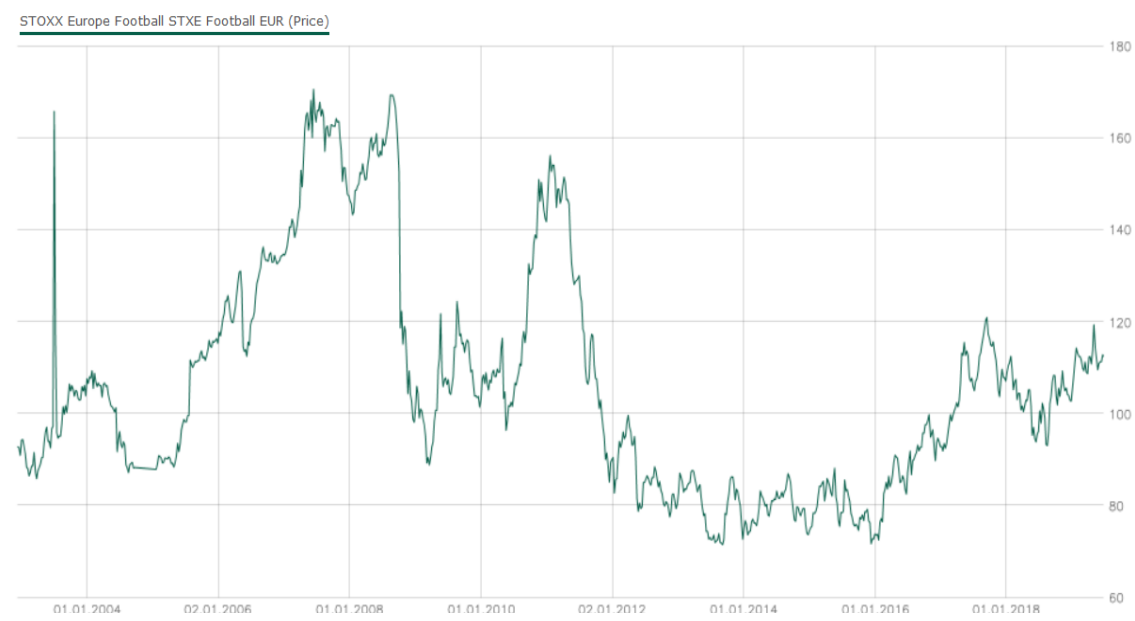

Figure 1.Evolution STOXX Europe Football Index Source: bttps: / mmm.wallstreet-online.de/ indizes/stoxx-europe-football-stxe-football-eur-price/

Listing sports clubs at BVB offers the possibility to finance activities through the stock market as an alternative to bank loans, through the issue of new securities (shares, bonds, etc.) and free advertising through the fact that the summary of the transactions in each trading session is transmitted to domestic and international press agencies, main newspapers and radio and television stations. At the same time it increases the reputation of the sports club through the commercial, credit and payment facilities that it can obtain from its suppliers and customers. International statistics shows that the stock exchange admission of securities issued by a publicly owned company 
increases its reputation and it generates an increase in the price of its shares with an average of about $20 \%$.

\section{Conclusion}

Following the study we can conclude that sports clubs are sports structures which function under Law no. 69/2000, and they can be organized as: non-profit private individuals; legal persons under the public law and joint-stock sports companies. Sports clubs can be established either as single-sports or multi-sports structures, having their own management and administration regime for the budget and the patrimony and implicitly a differentiated tax regime.

We can conclude that the form of organization of sports clubs in Romania generates peculiarities in their funding and implicitly represents a way of fiscal optimisation.

\section{References:}

[1] Juris Classeur St. D. Pénal des Affaires. V Impôts, Fasc. 10: Impôts- Fraude fiscale et infractions assimilées. Paris: Editura Lexis Nexis; 2004. 4 p.

[2] Pătroi D. Evaziunea fiscală: între latura permisivă, aspectul contravențional şi caracterul infracțional. Ed. Economică. 2007. 85 p.

[3] Graur A. Planificarea fiscală: instrument de optimizare a datoriilor față de buget, Journal „ECONOMICA”; 2017, 1: 99.

[4] OUG nr. 31 din 14 mai 2019 privind acordarea unor facilităţi fiscal şi pentru modificarea şi completarea Legii nr. 227/2015 privind Codul fiscal.

[5] Parlamentul României. Legea educației fizice şi sportului nr. 69/2000. Text publicat în Monitorul Oficial, Partea I nr. 200 din 09 mai 2000, în vigoare de la 07 august 2000.

[6] Ministerul Transportului și Tineretului. [Internet]. Available from: http://mts.ro/sport.

[7] MTS. Strategia de dezvoltare a sportului în România - perioada 2016 -2032, București; 2016. Available from: http://mts.ro/wpcontent/uploads/2017/01/Anexa3 Plan_ actiune_2016-2020_masuri_ST.pdf.

[8] Wallstreet online. Available from: https://www.wallstreetonline.de/indizes/stoxx-europe-football-stxe-football-eur-price. 